\title{
Effect Type of Solvent for Extraction Binahong Leaves (Anrederacordifolia (Ten.) Steenis) on Saponin Levels by Gravimetric Method
}

\author{
Sri Wardatun, Sutanto, Euis Mahmudah
}

\begin{abstract}
Secondary metabolites, also known as phytochemicals, natural products or plant constituents are responsible for medicinal properties of plants. The Secondary metabolite compounds contained in binahong leaves were steroids, alkaloids, flavonoids, saponins, polyphenols and tannins. The purpose of this research was for determine the content of saponin compounds in binahong leaves extract by gravimetric method with differents type of solvent. Binahong leaves made into simplicia and extracted using 3 types of solvents: $70 \%$ ethanol, $95 \%$ ethanol and methanol. The extraction was performed in reflux. The extract fractionated with n-hexane, ethyl acetate and $n$-butanol solvent, respectively. The levels of saponin in fraction n-butanol determined by gravimetric methods. The results showed that the type of solvent had an effect on the levels of isolated saponins. The methanol solvent produced the highest saponins in $54.30 \%$, 95\% ethanol in $35.84 \%$ and $70 \%$ ethanol in $25.91 \%$, respectively.
\end{abstract}

Index Terms: Binahong leaves, Saponins, Methanol, 70\% ethanol, 95\% ethanol.

\section{INTRODUCTION}

Binahong (Anrederacordifolia) is a succulent plants, it's has heart-shaped leaves and thick fleshy tubers. Some people consider binahong a destructive weed plant, but actually this plant has many health benefits. Phytochemical tests on ethanol extract of binahong leaves showed the presence of alkaloid compounds, flavonoids, tannins, triterpenoids / steroids and saponins [1].

Saponins are secondary metabolites with high molecular weight. Saponins are bitter in taste and in recent years, they have received considerable attention because of their various biological activities including hepatoprotective, anti-ulcer, anti-tumor, antimicrobial, adjuvant and anti-inflammatory activities [2]-[6]. Saponin can use as excipient as adjuvant activity and absorption enhancer. It's can use cosmetics and food industries too. The presence of saponins is very easily characterized because it's show detergent properties.

Generally, the extraction of saponins can be done by methanol [7] but Soni et al., 2017 [8] extracted saponins with 80\% ethanol too. Naveen and Asna 2015 [9] determined the level of saponin by gravimetric method the reflux method produced the maximum total saponins compared to the ultrasonic extraction and maceration methods [10].

This study aims to determine the highest saponin levels

Revised Manuscript Received on August 22, 2019.

Sri Wardatun, Department of Pharmacy, Pakuan University, Indonesia.

Sutanto, Department of Chemistry, Pakuan University, Indonesia.
Euis Mahmudah, Department of Pharmacy, Pakuan University, Indonesia.

from binahong leaves (Anrederacordifolia (Ten.) Steenis) extracted by $70 \%$ ethanol, $95 \%$ ethanol and methanol for study effect of type of solvent to levels saponins. The extraction method used reflux and saponins levels were determined by gravimetric method.

\section{MATHERIALS AND METHODS}

\section{A. Preparation of dry binahong leaves}

The binahong leaves were taken from Sringanis Park, Cipaku Bogor, Indonesia. Binahong leaves have been characterized at the Botanical Gardens-Plant Conservation Center, Bogor. Binahong leaves dried in an oven at $50^{\circ} \mathrm{C}$ for 72 hours then grinded into powders and sieved through a stainless steel sieve of 30 mesh. All chemical reagents used analysis reagent grade.

\section{B. Saponin Test Binahong Leaves Powder}

Five hundred milligram of binahong leaves powder shaken with $10 \mathrm{ml}$ of water, it's will produce a stable foam with the addition of hydrochloric acid [2].

\section{Preparation of Extract}

Fifty grams of binahong leaves powder and $500 \mathrm{ml}$ of $70 \%$ ethanol refluxed for 30 minutes. Ethanolic liquid extract obtained from filtered extract. The residual powder refluxed twice more, using $500 \mathrm{ml}$ of $70 \%$ ethanol, respectively. Ethanolic liquid extract is evaporated by rotary evaporator. This step repeated using 95\% ethanol and methanol, respectively.

\section{Saponin Test Binahong Leaves Extract}

Five hundred milligram of binahong extract shaken with $10 \mathrm{ml}$ of water, it's will produce stable foam with the addition of hydrochloric acid [2].

\section{E. Determination of Saponin Levels}

The extract weighed in 1.25 grams and refluxed with 50 $\mathrm{ml}$ of $\mathrm{n}$-hexane at $60-80^{\circ} \mathrm{C}$ for 30 minutes, respectively. After cooled, n-hexane solution removed and residue dissolved with $50 \mathrm{ml}$ of ethyl acetate, thenethyl acetate solution separated. The residue dissolved with n-butanol into a separating funnel 3 times with $50 \mathrm{ml}$, respectively. All butanolic solutions mixed and 
evaporated with the rotary evaporator. The thick extract dissolved with $10 \mathrm{ml}$ of methanol and dropped into a known weighing crucible contain of $50 \mathrm{ml}$ diethyl ether while stirring. The residue separated by evaporating and rinsed with $10 \mathrm{ml}$ of diethyl ether and evaporated again. The crucible has been dried and weighed until constant. The difference weight between crucible with residue and empty crucible was determined as the weight of saponins.

\section{RESULT AND DISCUSSION}

Phytochemical test of powder on binahong leaves positively contains saponins. These results corresponding with the research conducted by Elya et. al, that the phytochemical test of binahong leaf powder contains saponins [1]. The phytochemical test of $70 \%$ ethanol extract, 95\% and methanol from binahong leaves positively contained saponins.

The determination of saponin levels was started with fractionated extract with n-hexane, ethyl acetate and n-butanol to obtain more pure compounds. Initially, the extract is refluxed first with n-hexane. The n-hexane solvent used for removing lipophilic compounds such as fat / oil and night. After extracted with n-hexane, residue added with ethyl acetate. Ethyl acetate solutions separated to remove more polar compounds such as tannins or other compounds. The ethyl acetate residue added with n-butanol, and shaked. The n-butanol solution separated to obtain more pure compounds, namely saponins.The n-butanol solution evaporated and the residue dissolved with methanol and dropped diethyl ether while stirring until precipitate forms and the solvent is evaporated, and rinsed again with a small amount of diethyl ether. The function of diethyl ether as a constituent agent because saponins are not soluble in ether and can precipitate saponins. The residue dried in the oven and weighed to a constant weight. The residue obtained until constant weight is a saponin compound. The results of saponin content determination can be seen in Table 1 .

Table 1. Saponins levels

\begin{tabular}{|c|c|}
\hline Type of extract & $\begin{array}{c}\text { Average saponin level /gram } \\
\text { simplicia }\end{array}$ \\
\hline $70 \%$ ethanol & $6,75 \pm 1,95^{\mathrm{a}}$ \\
\hline $96 \%$ ethanol & $8,27 \pm 0,93^{\mathrm{b}}$ \\
\hline Methanol & $9,64 \pm 0,71^{\mathrm{c}}$ \\
\hline
\end{tabular}

Superscript signs state the difference in level saponins $(\mathrm{P}<0.05)$

The results of the study stated that methanol produced the highest saponins. This result is consistent with the research conducted by Pham et al. (2015) that methanol solvents produce higher saponin levels compared to ethanol solvents in Helictereshirsuta Lour leaves [11].

\section{CONCLUSION}

Methanol solvent produce the highest levels of saponins than $70 \%$ and $96 \%$ ethanol.

\section{REFERENCES}

1. B. Elya, R. Handayani, R. Sauriasari, R., Azizahwati, U. S. Hasyyati, I. T. Permana and Y. I. Permatasari. "Antidiabetic activity and phytochemical screening of extracts from indonesian plants by inhibition of alpha amylase, alpha glucosidase and dipeptidyl peptidase IV." Pakistan Journal of Biological Sciences, vol. 18, no. 6, pp. 273-278, 2015.

2.E. Moghimipour and S. Handali. "Saponin: Properties, Methods of Evaluation and Applications." Annual Research \& Review in Biology, vol. 5, no. 3, pp. 207-220, 2015.

3. R. A. V. I. Lokesh, V. Manasvi and B, P. Lakshmi. "Antibacterial and Antioxidant Activity of Saponin From Abutilon Indicum Leaves." Asian Journal of Pharmaceutical and Clinical Research, vol. 9, no. 9, pp. 344-347, 2016.

4. R. B. Konri, S. Samaddar and C. T. Ramaiah. Antidiabetic activity of a triterpenoid saponin isolated from Momordica cymbalaria Fenzl. Indian Journal of Experimental Biology, vol. 52, no. 1, pp. 46-52, 2014.

5. A. Smith. "In Vitro and in Vivo Antioxidant Activity of Saponin Extracted From the Root of Garcinia Kola ( Bitter Kola ) on Alloxan-Induced Diabetic Rats." World Journal of Pharmacy and Pharmaceutical Sciences, vol. 3, no. 7, pp. 8-26, 2014.

6. E. Moghimipour, B. Sadaghi-Nejad, S. Handali, A. Ameri, Z. Ramezani and M. E. Azemi. "In vitro screening of anti-Candida activity of saponins extracted from Glycyrrhiza glabra and Quillaja saponaria." Asian Journal of Pharmaceutical and Clinical Research, vol. 7, no. 1, pp. 160-162, 2014.

7. S. Odeyemi, A. Afolayan and G. Bradley. "In Vitro Anti-Inflammatory And Free Radical Scavenging Activities Of Crude." African Journal of Traditional, Complementary, and Alternative Medicines, vol. 12, no. 4, pp. 34-40, 2014.

8. A. Soni, P. Femida and P. Sharma. "In-vitro cytotoxic activity of plant saponin extracts on breast cancer cell-line." Research Journal of Pharmacognosy and Phytochemistry, vol. 9, no. 1, 17-22, 2017.

9. Y. P. Naveen and A. Urooj. "Pharmaceutical research". Asian Journal of Pharmaceutical Research, vol. 5, no. 3, pp. 161-166, 2015.

10.B. Zhao, W. Zhao and Z. Yuan. "Optimization of extraction method for total saponins from Codonopsis lanceolata." Asian Journal of Traditional Medicines, vol. 7, no. 1, pp. 14-17, 2012.

11.H. Pham, V. Nguyen, Q. Vuong, M. Bowyer and C. Scarlett. "Effect of Extraction Solvents and Drying Methods on the Physicochemical and Antioxidant Properties of Helicteres hirsuta Lour. Leaves." Technologies, vol. 3, no. 4, pp. 285-301, 2015. 